\title{
Analisis Pemahaman Konsep Gerak Lurus pada Siswa SMA Negeri di Kota Palu
}

\author{
Ma'rifa, H. Kamaluddin dan H. Fihrin \\ marifaidrus@gmail.com \\ Program Studi Pendidikan Fisika FKIP Universitas Tadulako \\ Jl. Soekarno Hatta Km. 9 Kampus Bumi Tadulako Tondo Palu - Sulawesi Tengah
}

\begin{abstract}
Penelitian ini bertujuan untuk mendeskripsikan pemahaman konsep gerak lurus pada siswa SMA Negeri di Kota Palu melalui metode Certainty of Response Index (CRI). Penelitian ini merupakan penelitian deskriptif-kualitatif. Subyek penelitian berjumlah 137 siswa yang dipilih berdasarkan pertimbangan telah mempelajari materi gerak lurus. Analisa data melalu tes pemahaman konsep sebanyak 19 soal yang telah divalidkan oleh judgement ahli, tes tersebut berupa soal pilihan ganda yang disertai dengan CRI sehingga kesulitan reponden dalam menjawab tes tersebut dapat diketahui. Hasil penelitian menunjukkan persentase siswa yang menebak sebesar $12,83 \%$, paham konsep sebesar 23,90\%, tidak paham konsep 29,88\%, dan miskonsepsi sebesar 33,39\%. Hal ini menunjukkan bahwa siswa SMA Negeri di Kota Palu pemahaman konsep gerak lurus masih sangat rendah. Maka perlu adanya perhatian dan remediasi mengenai materi gerak lurus karena akan mempengaruhi konsep siswa ke jenjang berikutnya.
\end{abstract}

Kata Kunci : analisis, pemahaman konsep, gerak lurus.

\section{PENDAHULUAN}

Fisika merupakan ilmu fundamental yang menjadi dasar perkembangan ilmu pengetahuan dan teknologi. Mengingat begitu pentingnya peranan ilmu fisika, sudah semestinya fisika dipahami dengan baik oleh siswa. Upaya siswa dalam mempelajari fisika sering menemui hambatan-hambatan. Fisika biasanya dianggap sebagai pelajaran yang sulit dipahami. Hal itu mungkin menyebabkan hasil belajar siswa menjadi kurang baik ${ }^{[1]}$.

Banyak siswa yang tidak memberikan hasil yang baik dalam pembelajarannya. Siswa tidak mengetahui cara-cara belajar yang efisien dan efektif karena hanya mencoba menghafal pelajaran. Padahal fisika bukan materi untuk dihafal, melainkan memerlukan penalaran dan pemahaman konsep. Akibatnya jika diberi tes, siswa mengalami kesulitan.

Mempelajari fisika tanpa memahami konsep-konsep tidaklah sesuai dengan hakekat IPA sebagai produk dan proses serta tidak sesuai proses belajar bermakna. Dalam kehidupan sehari-hari cukup banyak siswa yang berpikir bahwa jika dua benda bergerak dalam waktu dan percepatan yang sama maka jarak yang ditempuh sama pula. Kecepatan awal perlu diperhitungkan karena unsur tersebut yang membuat jaraknya berbeda. Menurut beberapa penelitian, salah pengertian terbanyak terjadi pada gerak parabola. Siswa masih sulit menangkap mengapa kecepatan pada puncak suatu proyektil adalah nol, meski percepatannya tidak nol. Mereka berpikir bahwa jika kecepatan itu nol, percepatannnya juga harus nol.

Sebelum memasuki ruang-ruang pembelajaran peserta didik telah memiliki konsepsi sendiri-sendiri tentang sesuatu, termasuk yang berkaitan dengan materi fisika. Sebelum mereka mengikuti pelajaran gerak lurus, mereka sudah banyak memiliki pengalaman dengan peristiwa-peristiwa tentang gerak (benda yang bergerak lurus, benda yang jatuh bebas, dan lain-lain). Pengalaman itu mereka telah memiliki konsepsi-konsepsi yang belum tentu sama dengan konsepsi fisikawan. Konsepsi seperti itu disebut dengan prakonsepsi. Mengatakan ${ }^{[2]}$ jika prakonsepsi siswa sering kali tidak cocok dengan pengetahuan yang diterima dari pakar, maka siswa tersebut akan mengalami miskonsepsi. Prakonsepsi siswa atas konsep fisika yang dibangun oleh siswa itu sendiri melalui belajar informal dalam upaya memberikan makna atas pengalaman meraka sehari-hari mempunyai peran yang sangat besar dalam pembentukan konsepsi ilmiah ${ }^{[3]}$. Prakonsepsi siswa yang pada umumnya bersifat miskonsepsi secara terus-menerus dapat mengganggu pembentukan konsepsi ilmiah.

Konsep gerak lurus merupakan salah satu pokok bahasan yang diajarkan di SMA kelas $X$ semester 1 . Bahwa beberapa ahli telah melakukan penelitian untuk mengungkap miskonsepsi pada konsep gerak lurus, diantaranya pada konsep percepatan gravitasi dimana siswa beranggapan bahwa sebuah 
benda yang lebih berat akan jatuh lebih cepat daripada benda yang ringan pada peristiwa gerak jatuh bebas. Pada kaitan konsep jarak dan perpindahan, siswa berpikir bahwa kedua konsep ini sama.

Sehubungan dengan hal di atas, maka dilakukan analisis pemahaman konsep siswa dalam pembelajaran fisika untuk mengevaluasi hasil dari pembelajaran yang telah diperoleh.

\section{METODE PENELITIAN}

Penelitian ini merupakan penelitian yang bertujuan untuk mendeskripsikan pemahaman konsep gerak lurus pada siswa SMA Negeri di Kota Palu. Konsep fisika yang diteliti dibatasi pada materi gerak lurus. Penelitian ini termasuk penelitian kualitatif yang mendeskripsikan fakta, fenomena yang terjadi pada subjek penelitian. Populasi dalam penelitian ini adalah seluruh siswa SMA Negeri
Hal tersebut akan membantu untuk menentukan standar dari kualitas pemahaman konsep siswa di sekolah. Analisis pemahaman konsep siswa dalam pembelajaran fisika dilakukan untuk mengevaluasi hasil dari pembelajaran yang telah diperoleh. Pada penelitian ini akan diungkapkan konsep alternatif fisika yang dimiliki siswa.

di Kota Palu. Sampel yang digunakan adalah siswa SMA Negeri Kelas XI yang berjumlah 137 siswa. Sampel dipilih atas pertimbangan telah mempelajari materi gerak lurus. Tes pemahaman konsep yang digunakan pada penelitian ini sebanyak 19 nomor. Untuk membedakan antara paham konsep, dan tidak paham konsep digunakan CRI (Certainty of Response Index).

\section{HASIL PENELITIAN DAN PEMBAHASAN}

Hasil penelitian yang telah dilakukan dengan menggunakan tes pemahaman konsep dapat dilihat pada Gambar 1.

\section{Persentase Pemahaman Siswa (\%)}

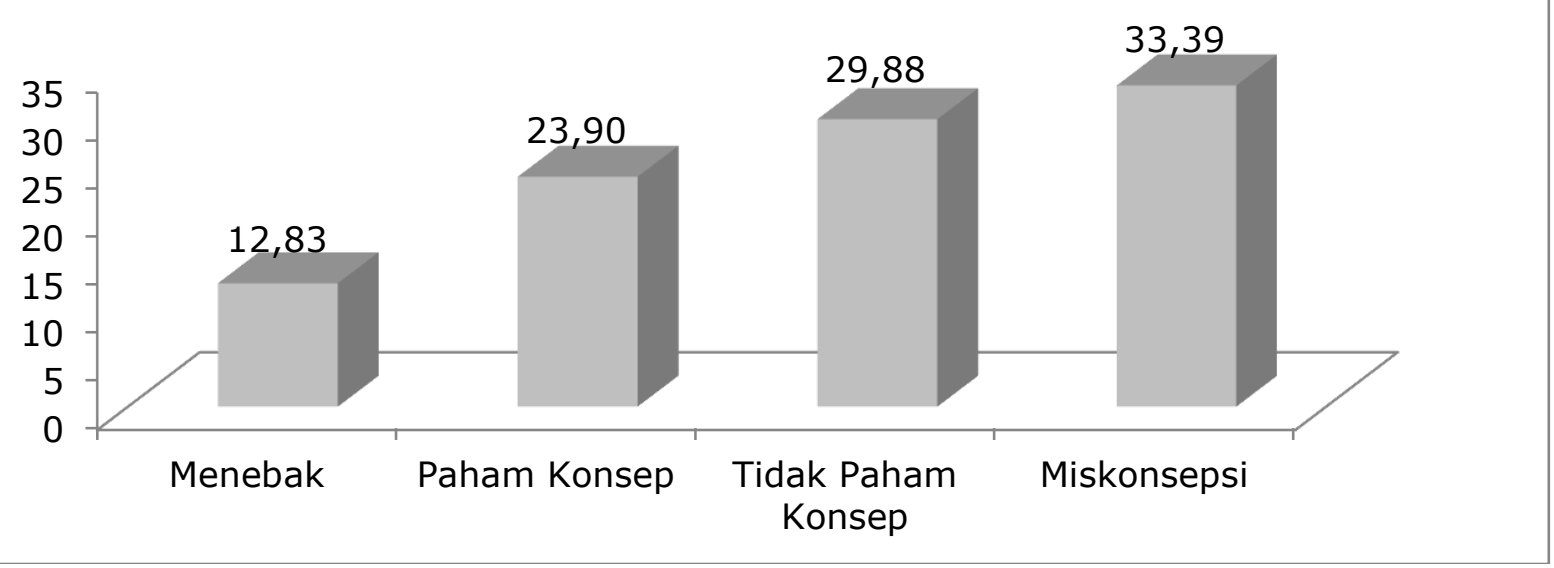

Gambar 1. Persentase Pemahaman Siswa

Berdasarkan Gambar 1 dapat dilihat bahwa persentase miskonsepsi 33,39\%. Terjadinya miskonsepsi disebabkan oleh konsep awal siswa yang salah. Selain itu, dipengaruhi oleh pengalaman sehari-hari siswa, seperti banyak siswa yang berpikir bahwa jika dua benda bergerak dalam waktu dan percepatan yang sama maka jarak yang ditempuh sama pula.

Konsep-konsep fisika yang dipahami salah adalah konsep gerak jatuh bebas. Pada umumnya siswa beranggapan ketika benda $A$ dan benda $B$ berada pada ketinggian tertentu, kemudian saling dijatuhkan bebas. Benda A lebih dahulu dijatuhkan baru kemudian benda B, maka jarak antara A dan B selama masih bergerak di udara adalah mengecil dahulu Ialu tetap.

Konsep-konsep fisika yang dipahami salah adalah konsep gerak lurus berubah beraturan. Pada umumnya siswa beranggapan, pada ticker timer hasil ketukan jejak-jejak gerak lurus pada pita kertas saat terjadi gerak lurus dipercepat beraturan ditunjukan ketika 
jarak antar titik semakin lama semakin dekat. Demikian juga untuk kasus seorang yang sedang mengendarai mobil dengan kecepatan $90 \mathrm{~km} / \mathrm{jam}$, tiba-tiba melihat seorang anak kecil berdiri ditengah jalan pada jarak $200 \mathrm{~m}$ didepannya. Jika mobil direm dengan perlambatan maksimum $1,25 \mathrm{~m} / \mathrm{s}^{2}$, maka mobil tepat akan berhenti dimuka anak.

Konsep-konsep fisika yang dipahami salah adalah konsep besaran-besaran pada gerak lurus pada umunya siswa beranggapan jika sebuah bola meluncur ke bawah pada sebuah lengkungan maka kelajuan dan kecepatannya bertambah dan sudut kemiringan lengkungan pada setiap ketinggian sama. Demikian juga untuk kasus grafik kecepatan terhadap waktu untuk suatu bola yang dilempar vertikal ke atas dan kembali pada pelempar setelah mencapai ketinggian tertentu adalah awalnya benda melakukan gerakan jatuh bebas lalu melakukan gerakan vertikal ke atas.

\section{KESIMPULAN}

Berdasarkan hasil penelitian yang telah dilakukan, maka diperoleh kesimpulan yaitu :

1. Siswa SMAN di Kota Palu mengalami miskonsepsi pada materi gerak lurus. Persentase miskonsepsi yang dialami siswa SMAN di Kota Palu sebesar 33,39\%. Hal ini menunjukkan kesalahpahaman konsep yang dialami oleh siswa cukup tinggi.

2. Bentuk-bentuk pemahaman konsep siswa diantaranya yaitu:

a) Benda A dan B yang jatuh bebas, selama masih bergerak di udara jaraknya adalah mengecil dahulu lalu tetap.

b) Pada ticker timer hasil ketukan jejakjejak gerak lurus pada pita kertas saat terjadi gerak lurus dipercepat beraturan ditunjukan ketika jarak antar titik semakin lama semakin dekat.

c) Seorang yang sedang mengendarai mobil dengan kecepatan seseorang dalam 90 $\mathrm{km} / \mathrm{jam}$, tiba-tiba melihat seorang anak kecil berdiri ditengah jalan pada jarak $200 \mathrm{~m}$ dimukanya. Mobil direm dengan perlambatan maksimum $1,25 \mathrm{~m} / \mathrm{s}^{2}$, maka mobil tepat akan berhenti dimuka anak.

d) Bola yang meluncur ke bawah pada sebuah lengkungan maka kelajuan dan kecepatannya bertambah.

e) Grafik kecepatan terhadap waktu untuk suatu bola yang dilempar vertikal ke atas dan kembali pada pelempar setelah mencapai ketinggian tertentu adalah awalnya benda melakukan gerakan jatuh bebas lalu melakukan gerakan vertikal ke atas.

\section{DAFTAR PUSTAKA}

[1] Pujianto, Agus. (2013). Analisis Konsepsi Siswa pada Konsep Kinematika Gerak Lurus. 1, (1), 3-6.

[2] Suparno. 2005. Miskonsepsi \& Perubahan Konsep Pendidikan Fisika. Jakarta: PT.Grasindo.

[3] Trumper, Ricardo. (1990). Being Constructive: An Alternative Approach to the Teaching of Energy Concept. International Journal of Science Education. Vol. 12, No. 4. 